\title{
ANALISIS EVA DAN MVA PADA PERUSAHAAN JAKARTA ISLAMIC INDEKS
}

\author{
Ghazali Syamni \\ Dosen Fakultas Ekonomi dan Bisnis Universitas Malikussaleh
}

\begin{abstract}
Abstrak
Tujuan penelitian ini adalah menganalisis kinerja keuangan berdasarkan economic value added (EVA) dan market value added (MVA) pada saham yang termasuk di Jakarta Islamic Indeks. Penggunaan analisis ini dikarenakan kinerja perusahaan dengan menggunakan kinerja tradisi belum mencermin nilai ekonomi dari perusahaan. Di masa yang akan datang. Hasil penelitian menemukan bahwa nilai Economic Value Added pada tahun 2011 sampai dengan 2013 tertinggi dimiliki oleh perusahaan United Tractor Tbk. Sementara Market Value Added tertinggi oleh perusahaan Indocement Tunggal Prakarsa Tbk. Pada tahun 2012 PT Charoen Pokhpand Tbk sedangkan pada tahun 2013 kembali pada perusahaan Indocement Tunggal Prakarsa Tbk. Di sisi lain nilai terendah untuk Economic Value Added pada tahun 2011 sampai dengan 2013 adalah Kalbe Farma Tbk, perusahaan Telekomunikasi Indonesia Tbk, dan Kalbe Farma Tbk. Sementara Market Value Added nilai terendah pada tahun 2011 sampai 2013 adalah PT . London Sumatera Plantation Tbk
\end{abstract}

Katakunci: kinerja, keuangan, EVA, MVA

\begin{abstract}
The purpose of this study was to analyze financial performance based on economic value added (EVA) and market value added (MVA) in shares included in the Jakarta Islamic Index. The use of this analysis due to the company's performance using the performance tradition not reflect the economic value of the company. In the future. The results found that the value of Economic Value Added in 2011 to 2013 the highest owned by United Tractor Tbk. While the highest Market Value Added by company Indocement Tbk. In 2012 PT Charoen Pokhpand Tbk whereas in 2013 returned to the company Indocement Tbk. On the other hand the lowest value for Economic Value Added in 2011 to 2013 is Kalbe Farma Tbk, the company Telekomunikasi Indonesia Tbk, and Kalbe Farma Tbk. While the Market Value Added lowest value in 2011 until 2013 were PT. London Sumatra Plantation Tbk
\end{abstract}

Katakunci: performance, Financial, EVA, MVA 


\section{PENDAHULUAN}

Analisis kinerja perusahaan dibutuhkan oleh para investor untuk dapat menilai prospek perusahaan di masa yang akan datang. Apabila kinerja perusahaan baik makan sahamnya akan terus diminati dan harganya akan meningkat sehingga return yang diterima juga akan meningkat. Namun jika kinerja perusahaan buruk maka investor tidak akan mau berinvestasi di perusahaan tersebut karena di anggap berisiko dan tidak mampu memberikan return yang optimal.

Dalam menilai kinerja perusahaan biasanya investor akan melihat dan menganalisis laporan keuangan perusahaan. Banyak alat yang digunakan untuk mengukur kinerja keuangan Ikbar dan Dewi (2015). Metode yang telah banyak digunakan untuk menilai kinerja keuangan perusahaan a menggunakan rasio keuangan. Perhitungan rasio keuangan ini dapat dengan mudah dilakukan, namun kelemahan metode ini adalah tidak dapat mengukur kinerja perusahaan dari sisi nilai perusahaan. Gulo dan Ermawati (2011). Kelemahan merode biasanya metode ini disebut dengan metode akuntansi. Pinto dan Santos (2011) menyebutkan metode akuntansi ini kemungkinan gagal dalam mengukur nilai ekonomi sebuah perusahaan, seperti: laba akuntansi tidak dibutuhkan dalam menciptakan nilai ekonomi bagi pemegang saham, kenaikan nilai perusahaan jika perusahaan memperoleh investasi baru. Dengan demikian dalam mengukur dalam menciptakan nilai ekonomi (Economic Value Added dan Market Value Added, EVA dan MVA)).

Konsep EVA dan MVA dicetuskan oleh Stern Stewart Manajemen Services (SSMS) dari Stern \& Stewart Co. of New York City pada tahub 1989 sebagai alat ukur kinerja keuangan dan pasar untuk mengetahui kelemahan metode sebelumnya. Brigham \& Houston (2010) mengemukakan bahwa EVA merupakan estimasi laba ekonomi usaha yang sebenarnya untuk tahun tertentu, yang menunjukkan sisa laba setelah biaya modal. Perusahaan yang memiliki EVA tinggi maka cenderung akan menarik investor untuk berinvestasi, karena semakin tinggi EVA maka semakin tinggi nilai perusahaan. Panggabean (2005) EVA adalah laba usaha (operating profit) yang dikurangi dengan biaya seluruh modal (capital) yag dipakai sehingga menghasilkan pendapatan (earning). Warsono (2001) menyatakan bahwa EVA adalah perbedaan antara laba operasi setelah pajak dengan biaya modal yang merupakan suatu estimasi laba ekonomis yang benar atas suatu bisnis selama tahun tertentu. Sedangkan menurut Tandelilin (2010) yang menyatakan bahwa EVA merupakan pengukuran keberhasilan manajemen perusahaan dalam meningkatkan nilai tambah bagi perusahaan

Sementara itu, definisi EVA mempunya hubungan dengan Market Value Added. Brigham \& Houston (2010) menyatakan bahwa Market Value Added adalah perbedaan antara nilai pasat 
ekuitas suatu perusahaan dengan nilai buku yang disajikan dalam neraca, nilai pasar dihitung dengan mengalikan harga saham dengan jumlah saham yang beredar. Semakin besar MVA berarti semakin baik. MVA yang negatif berarti nilai dari investasi yang dijalankan manajemen kurang dari modal yang diserahkan kepada perusahaan oleh pasar modal, yang berarti bahwa kekayaan telah dimusnahkan (Young dan O’Byme, 2001). Menurut Sartono (2001), tujuan utama perusahaan adalah memaksimalkan kemakmuran pemegang saham. Selain memberi manfaat bagi pemegang saham, tujuan ini juga menjamin sumber daya perusahaan yang langka dialokasikan secara efisien dan memberi manfaat ekonomi. Kemakmuran pemegang saham dimaksimalkan dengan memaksimalkan kenaikan nilai pasar dari modal perusahaan di atas nilai modal yang disetor pemegang saham. Kenaikan ini disebut Market Value Added (MVA).

Menurut Melani (2007) MVA adalah indikator eksternal yang mengukur seberapa besar kekayaan perusahaan yang telah diciptakan untuk investornya atau dapat dikatakan MVA merupakan seberapa besar kemakmuran yang telah dicapai atau dihilangkan oleh suatu perusahaan. Djawahir (2007) MVA diperoleh dengan menghitung nilai perusahaan, penjumlahan harga pasar seluruh saham, surat utang dan surat berharga lainnya yang dimaksudkan untuk mobilitasi capital yang dikurangi dengan nilai buku atau modal yang diinvestasikan. Sedangkan menurut Young dan O'Byme (2001) menyatakan bahwa MVA adalah perbedaan antara nilai pasar perusahaan (termasuk ekuitas dan utang) dan modal keseluruhan yang diinvestasikan dalam perusahaan. MVA merupakan hasil kumulatif dari kinerja perusahaan yang dihasilkan oleh berbagai investasi yang telah dilakukan maupun yang akan dilakukan. Dengan demikian, peningkatan MVA merupakan keberhasilan perusahaan dalam memaksimalkan kekayaan pemegang saham dengan alokasi sumber-sumber (Gulo dan Ermawati (2011).

Dari beberapa definisi diatas, dapat disimpulkan bahwa Market Value Added (MVA) adalah pengukuran kinerja eksternal yang mengakumulasikan kinerja perusahaan dari berbagai investasi dengan alokasi sumber daya yang tepat dan sesuai sehingga menciptakan nilai kemakmuran bagi investornya.

\section{DATA DAN METODE}

\section{Data}

Data yang digunakan dalam penelitian ini adalah laporan keuangan perusahaan yang terdaftar di Jakarta Islamic Index (JII) periode 2011-2014. Dalam penelitian ini yang akan menjadi objek penelitian yaitu Economic Value Added, Market Value Added. Dalam memperoleh 
data dalam penelitian ini dengan mengakses di situs $\underline{\text { www.idx.com, }} \underline{\text { www.sahamok.com dan }}$ www.ojk.com. Perusahaan yang terdaftar di Jakarta Islamic Index (JII) periode 2011 sampai 2014 yang terdiri dari 53 perusahaan. Namun selama periode waktu tersebut yang memilik data hanya 12 perusahaan.

Adapun perusahaan tersebut adalah Astra Agro Lestari Tbk. Astra International Tbk. Charoen Pokpand Tbk. Indocement Tunggal Prakarsa Tbk. Indo Tambangraya Megah Tbk. Kalbe Farma Tbk. PP London Sumatera Plantation Tbk. Tambang Batubara Bukit Asam (Persero) Tbk, Semen Indonesia (Persero) Tbk. Telekomunikasi Indonesia (Persero) Tbk. United Tractors Tbk dan Unilever Indonesia Tbk

\section{Definis Operasional Variabel}

\section{Economic Value Added (EVA)}

EVA mengukur nilai tambah (value creation) yang dihasilkan suatu perusahaan dengan cara mengurangi beban biaya modal (cost of capital) yang timbul sebagai akibat dari investasi yang dilakukan. EVA dapat dihitung dengan menggunakan rumus Young dan O'Byme (2001) sebagai berikut:

$$
\mathrm{EVA}=\mathrm{NOPAT}-(\mathrm{WACC} \mathrm{x} \text { Invested Capital })
$$

$\mathrm{EVA}=$ NOPAT - Capital Charges

Perhitungan dengan metode EVA adalah sebagai berikut:

1. Net Operating Profit After Tax (NOPAT)

$$
\text { NOPAT }=(\text { Laba bersih } x \text { expenses })-\text { Tax }
$$

2. Invested Capital

Invested Capital $=$ Total Asset - Hutang lancar

3. Weighted Average Cost of Capital (WACC)

$$
\mathrm{WACC}=[(\mathrm{D} \times \mathrm{rd})(1-\mathrm{t})+(\mathrm{E} \times \mathrm{re})]
$$

Keterangan: 
Tingkat Modal (D) $=\frac{\text { Total Hutang }}{\text { Total Hutang dan Ekuitas }} \times 100 \%$

Cost of Debt $(\mathrm{rd})=\frac{\text { Beban Bunga }}{\text { Total Hutang Jangka Panjang }} \times 100 \%$

Tingkat Modal dari Ekuitas $(E)=\frac{\text { Total Ekuitas }}{\text { Total Hutang dan Ekuitas }} \times 100 \%$

Cost of Equity (re) $=\frac{\text { Laba Bersih Setelah Pajak }}{\text { Total Ekuitas }} \times 100 \%$

Tingkat Pajak $(\operatorname{tax})=\frac{\text { Beban Pajak }}{\text { Laba Bersih Sebelum Pajak }} \times 100 \%$

\section{Market Value Added (MVA)}

MVA merupakan selisih antara nilai pasar saham dengan modal sendiri yang disetor oleh pemegang saham. Nilai pasar saham adalah perkalian jumlah saham beredar dengan harga saham. Harga saham di dapat dari harga saham rata-rata dalam satu tahun. (Husnan dan Pudjiastuti, 2004 ). MVA t ditulis dengan rumus: (Brigham dan Houston, 2010).

MVA $=($ Harga saham $x$ Jumlah saham yang beredar $)-$ Total Nilai Ekuitas

\section{Metodel Penelitian}

Metode analisis data yang digunakan dalam penelitian ini adalah metode deskriptif kuantitatif, metode ini hanya mencarinilai Economic Value Added (EVA), Market Value Added (MVA) selama periode sampel penelitian, yaitu 2011-2014.

\section{HASIL PENELITIAN}

Deskrpsi analisis EVA

EVA adalah keuntungan operasi setelah pajak, dikurangi biaya modal yang yang di gunakan untuk menilai kinerja perusahaan dengan memperhatikan secara adil harapan para pemegang saham dan kreditur. EVA merupakan merupakan perangkat finansial untuk mengukur keuntungan nyata perusahaan. Hal ini membuat perhitungan EVA lain dengan perhitungan analisis rasio keuangan lainya. Perbedaan tersebut dikarenakan pada perhitungan dengan menggunakan pendekatan EVA melibatkan biaya modal operasi setelah laba bersih, dimana hal tersebut tidak dilakukan dalam perhitungan konvensional. Berikut tabel hasil perhitungan EVA untuk 12 sampel perusahaan yang terdaftar di JII: 
Tabel 1 Economic Value Added (EVA) Perusahaan JII Periode 2011-2014

\begin{tabular}{|c|c|c|c|c|c|}
\hline \multirow{2}{*}{ No } & \multirow{2}{*}{$\begin{array}{c}\text { Kode } \\
\text { Perusahaan }\end{array}$} & \multicolumn{4}{|c|}{ Tahun } \\
\hline & & 2011 & 2012 & 2013 & 2014 \\
\hline 1 & AALI & -1.910 .997 & -2.810 .903 & -2.802 .035 & -1.018 .719 \\
\hline 2 & ASII & -4.964 .837 & -1.575 .076 & -2.328 .839 & -4.386 .631 \\
\hline 3 & CPIN & -740.314 & -599.708 & -619.311 & -307.437 \\
\hline 4 & INTP & -2.419 .699 & -4.526 .035 & -5.653 .873 & -8.290 .639 \\
\hline 5 & ITMG & -8.080 .968 & -5.945 .177 & -7.730 .204 & -6.685 .706 \\
\hline 6 & KLBF & -26.790 .053 & -30.252 .442 & -44.040 .374 & -36.192 .582 \\
\hline 7 & LSIP & -499.924 & -471.522 & -513.151 & -379.022 \\
\hline 8 & PTBA & -1.046 .903 & -750.060 & -700.312 & -805.117 \\
\hline 9 & SMGR & -1.990 .980 & -2.037 .404 & -2.909 .288 & -3.187 .541 \\
\hline 10 & TLKM & -13.626 .625 & -48.362 .000 & -20.580 .968 & -25.144 .490 \\
\hline 11 & UNTR & -8.594 .930 & -13.342 .810 & -14.995 .180 & -3.165 .626 \\
\hline 12 & UNVR & 7.830 .504 & 9.648 .685 & 12.338 .278 & 12.045 .937 \\
\hline & Max & 7.830 .504 & 9.648 .685 & 12.338 .278 & 12.045 .937 \\
\hline & Min & -26.790 .053 & -48.362 .000 & -44.040 .374 & -36.192 .582 \\
\hline & Rata-rata & -5.236 .311 & -8.418 .704 & -7.544 .605 & -6.459 .798 \\
\hline
\end{tabular}

Sumber: wwww.sahamok.com (Data diolah, 2016)

Berdasarkan Tabel 1 menunjukkan keseluruhan data Economic Value Added (EVA) yang diteliti dalam penelitian ini. Dari hasil perhitungan tersebut menunjukkan bahwa pada tahun 2011 nilai maksimum EVA sebesar 7.830.504 dimiliki oleh perusahaan United Tractors Tbk. (UNTR), nilai minimum tahun 2011 sebesar -26.790.053 dimiliki oleh perusahaan Kalbe Farma Tbk. (KLBF). Pada tahun 2012 nilai maksimum EVA sebesar 9.648.685 dimiliki oleh perusahaan United Tractors Tbk. (UNTR), nilai minimum tahun 2012 sebesar -48.362 .000 dimiliki oleh perusahaan Telekomunikasi Indonesia (Persero) Tbk. (TLKM). Pada tahun 2013 nilai maksimum EVA sebesar 12.338.278 dimiliki oleh perusahaan United Tractors Tbk. (UNTR), nilai minimum tahun 2013 sebesar -44.040.374 dimiliki oleh perusahaan Kalbe Farma Tbk. (KLBF). Sedangkan pada tahun 2014 nilai maksimum EVA sebesar 12.045.937 dimiliki oleh perusahaan United Tractors Tbk. (UNTR) dan nilai minimum sebesar -36.192.582 dimiliki oleh perusahaan Kalbe Farma Tbk. (KLBF).

Nilai rata-rata EVA pada tahun 2011 sebesar -5.236.311. Tahun 2012 sebesar -8.418 .704$ (naik sebesar 3.182.393). Dan pada tahun 2013 sebesar -7.544.605 (turun sebesar 874.099). Dan pada tahun 2014 rata-rata EVA sebesar -6.459.798 (turun sebesar 1.084.807). Hal ini menunjukkan bahwa perusahaan memperoleh nilai EVA yang berubah-ubah setiap tahunnya 
pada perusahaan yang terdaftar di Jakarta Islamic Index periode 2011-2014. Perusahaan yang melakukan investasi tinggi dimana biaya modal yang dikeluarkan jauh lebih tinggi dari tingkat pengembalian yang diterima akan menghasilkan nilai negatif selama beberapa tahun, padahal belum tentu perusahaan tersebut mempunyai kinerja keuangan yang buruk.

\section{Deskriptif analisis MVA}

MVA merupakan suatu ukuran yang digunakan untuk mengukur keberhasilan dalam memaksimalkan kekayaan pemegang saham dengan mengalokasikan sumber-sumber dana yang sesuai. Nilai pasar mencerminkan keputusan pasar mengenai manajer yang sukses yang telah menginvestasikan modal yang sudah dipercayakan kepadanya. Semakin besar MVA makan akan semakin baik. MVA negatif berarti memiliki nilai yang dijalankan manajemen kurang dari modal yang diserahkan kepada perusahaan oleh pasar modal. Berikut ini tabel hasil perhitungan MVA untuk 12 sampel perusahaan yang terdaftar di JII:

Tabel 2 Market Value Added Perusahaan JII Periode 2011-2014

\begin{tabular}{|c|l|r|r|r|r|}
\hline \multirow{2}{*}{ No } & \multirow{2}{*}{$\begin{array}{c}\text { Kode } \\
\text { Perusahaan }\end{array}$} & \multicolumn{4}{|c|}{ Tahun } \\
\cline { 3 - 6 } & & $\mathbf{2 0 1 1}$ & $\mathbf{2 0 1 2}$ & $\mathbf{2 0 1 3}$ & $\mathbf{2 0 1 4}$ \\
\hline 1 & AALI & 23.973 .005 & 18.607 .680 & 24.569 .310 & 19.635 .421 \\
\hline 2 & ASII & 146.060 .600 & 125.404 .400 & 61.297 .200 & 64.564 .700 \\
\hline 3 & CPIN & 26.461 .246 & 47.504 .073 & 39.621 .053 & 41.122 .001 \\
\hline 4 & INTP & 609.493 .269 & 803.674 .240 & 709.632 .759 & 891.415 .027 \\
\hline 5 & ITMG & 29.360 .897 & 32.531 .364 & 15.123 .442 & 1.115 .570 \\
\hline 6 & KLBF & 26.255 .846 & 44.408 .842 & 47.278 .689 & 73.356 .217 \\
\hline 7 & LSIP & 8.559 .891 & 8.141 .104 & 5.193 .514 & 4.240 .324 \\
\hline 8 & PTBA & 28.467 .296 & 22.061 .419 & 11.823 .645 & 13.987 .977 \\
\hline 9 & SMGR & 48.259 .797 & 67.443 .116 & 53.144 .916 & 61.783 .734 \\
\hline 10 & TLKM & 39.074 .000 & 71.079 .000 & 88.769 .000 & 147.897 .000 \\
\hline 11 & UNTR & 51.845 .438 & 23.180 .367 & 13.507 .756 & 4.423 .469 \\
\hline 12 & UNVR & 132.961 .688 & 147.100 .521 & 185.031 .812 & 232.168 .330 \\
\hline & Max & $\mathbf{6 0 9 . 4 9 3 . 2 6 9}$ & $\mathbf{8 0 3 . 6 7 4 . 2 4 0}$ & $\mathbf{7 0 9 . 6 3 2 . 7 5 9}$ & $\mathbf{8 9 1 . 4 1 5 . 0 2 7}$ \\
\hline & Min & $\mathbf{8 . 5 5 9 . 8 9 1}$ & $\mathbf{8 . 1 4 1 . 1 0 4}$ & $\mathbf{5 . 1 9 3 . 5 1 4}$ & $\mathbf{1 . 1 1 5 . 5 7 0}$ \\
\hline & Rata-rata & $\mathbf{9 7 . 5 6 4 . 4 1 4}$ & $\mathbf{1 1 7 . 5 9 4 . 6 7 7}$ & $\mathbf{1 0 4 . 5 8 2 . 7 5 8}$ & $\mathbf{1 2 9 . 6 4 2 . 4 8 1}$ \\
\hline
\end{tabular}

Sumber: wwww.sahamok.com (Data diolah, 2016)

Berdasarkan Tabel 2 menunjukkan data Market Value Added (MVA) yang diteliti dalam penelitian ini. Hasil perhitungan menunjukkan bahwa pada tahun 2011 nilai maksimum MVA sebesar 609.493.269 dimiliki oleh perusahaan Indocement Tunggal Prakasa Tbk. (INTP) nilai 
minimum tahun 2011 sebesar 8.559.891 dimiliki oleh perusahaan PP London Sumatera Plantation Tbk. (LSIP). Pada tahun 2012 nilai maksimum MVA sebesar 803.674.24 dimiliki oleh perusahaan Charoen Pokhpand Tbk. (CPIN), nilai minimum tahun 2012 sebesar 8.141.104 dimiliki oleh perusahaan PP London Sumatera Plantation Tbk. (LSIP). Pada tahun 2013 nilai maksimum MVA sebesar 709.632.759 dimiliki oleh perusahaan Indocement Tunggal Prakasa Tbk. (INTP) nilai minimum tahun 2013 sebesar 5.193.514 dimiliki oleh perusahaan PP London Sumatera Plantation Tbk. (LSIP). Sedangkan pada tahun 2014 nilai maksimum MVA sebesar 891.415.027 dimiliki oleh perusahaan Indocement Tunggal Prakasa Tbk. (INTP) dan nilai minimum sebesar 1.115.570 dimiliki oleh perusahaan Indo Tambangraya Megah Tbk. (ITMG).

Serta nilai rata-rata Market Value Added (MVA) pada tahun 2011 sebesar 97.564.414. Tahun 2012 sebesar 117.594 .677 (naik sebesar 20.030.263). Dan pada tahun 2013 sebesar 104.582.758 (turun sebesar 13.011.919). Dan pada tahun 2014 rata-rata return saham sebesar 129.642.481 (naik sebesar 25.059.723). Hal ini menunjukkan bahwa perusahaan memperoleh Market Value Added (MVA) yang berubah-ubah setiap tahunnya pada perusahaan yang terdaftar di Jakarta Islamic Index periode 2011-2014. Perusahaan yang memiliki nilai MVA positif menunjukkan bahwa pihak manajemen perusahaan berhasil menciptakan nilai bagi pemegang saham artinya market value lebih besar dari book value.

\section{KESIMPULAN}

Analisis Economic Value Added dan Market Value Added keduanya mengukur kinerja perusahaan dalam memberikan nilai ekonomi bagi perusahaan. Dari sisi EVA lebih melihat prospek perusahaan di masa yang akan datang. Meskipun saat ini negatif belum tentu memiliki kinerja keuangan yang tidak baik. Sementara MVA yang memiliki nilai MVA positif menunjukkan pihak manajemen perusahaan mampu atau berhasil menciptakan nilai perusahaan bagi pemegang saham lebih baik.

Hasil penelitian, hasil analisis data didapatkan bahwa nilai Economic Value Added pada tahun 2011 sampai dengan 2013 tertinggi dimiliki oleh perusahaan United Tractor Tbk. Sementara Market Value Added tertinggi oleh perusahaan Indocement Tunggal Prakarsa Tbk. Pada tahun 2012 PT Charoen Pokhpand Tbk sedangkan pada tahun 2013 kembali pada perusahaan Indocement Tunggal Prakarsa Tbk. Di sisi lain nilai terendah untuk Economic Value Added pada tahun 2011 sampai dengan 2013 adalah Kalbe Farma Tbk, perusahaan Telekomunikasi Indonesia Tbk, dan Kalbe Farma Tbk. Sementara Market Value Added nilai terendah pada tahun 2011 sampai 2013 adalah PT . London Sumatera Plantation Tbk. 


\section{REFERENSI}

Brigham, Eugene F dan Houston, J. (2010). Dasar-dasar Manajemen Keuangan. Edisi 11. Salemba Empat. Jakarta

Djawahir, Kusnan M. (2007). SWA 100 Peringkat EVA dan MVA Terbaik 2007: Para Pencetak Kekayaan di Pasar Modal. Majalah SWA. Edisi No.26/2007.

Gulo, Wilmar Amonio dan Ermawati, Wita Juwita (2011). Analisis Economic Value Added (EVA) dan Market Value Added(MVA) sebagai Alat Pengukur Kinerja Keuangan PT SA, Jurnal Manajemen dan Organisasi Vol II, No. 2, Hal. 123-133

Husnan, Suad dan Enny Pudjiastuti. (2004). Dasar-dasar Manajemen Keuangan. UPP AMP YKPN, Yogyakarta.

Ikbar, Muhammad Mara dan Dewi, Andrieta Shintia (2015)The Analysis of Effect of Economic Value Added and Market Value Added on Share Price of Subsector Companies of Property Incorporated in LQ-45 Indonesia Stock Exchange in Period of 2009-2013, International Journal of Science and Research, Volume 4 Issue 4. Hal. 2310-2314

Melani K. Hardiman. (2007). Para Pencetak Kekayaan di Pasar Modal. Majalah SWA, 26/XX111/ 6-17 Desember, Hal 44.

Panggabean, Raja Lambas. 2005. Analisis Perbandingan Korelasi EVA dan ROE terhadap Harga Saham LQ 45 di BEJ. Jurnal Manajemen dan Bisnis Sriwijaya, Vol 3 No. 5. Hal. 1-19.

Pinto, Teresa da Cunha dan Santos, C. Machado (2011), an analysis of the correlation between eva and mva: the case of a nyse euronext Lisbon listed company. Global Journal of International Business Research Vol. 4. No. 4. Hal. Hal.70-79

Tandelilin, Eduardus. (2010). Portofolio dan Investasi Teori dan Aplikasi. Edisi pertama. Kanisius. Yogyakarta.

Warsono. (2001). Manajemen Keuangan Perusahaan. Edisi Ketiga. Cetakan Pertama. Jilid Satu. Bayu Media. Malang.

Young S. David dan Stephen F. O’Byrne. (2001). EVA \& Manajemen Berdasarkan Nilai. Edisi Pertama. Salemba Empat. Jakarta. 